\title{
Angiotensin-I-converting enzyme-inhibitory peptides in commercial Wisconsin Cheddar cheeses of different ages
}

\author{
Y. Lu, S. Govindasamy-Lucey, and J. A. Lucey ${ }^{1}$ \\ Wisconsin Center for Dairy Research, University of Wisconsin-Madison, Madison 53706
}

\section{ABSTRACT}

Bioactive peptides, including angiotensin-I-converting enzyme-inhibitory (ACEI) peptides, were investigated in commercially produced Wisconsin Cheddar cheeses that ranged in age from $\leq 6 \mathrm{~d}$ to more than $2 \mathrm{yr}$. The ACEI activity of cheese was determined in water-soluble extracts (WSE) that were fractionated for components with molecular weight $(\mathrm{MW}) \leq 3,000 \mathrm{Da}$, and peptides identified using HPLC and tandem mass spectrometry. The number of types of bioactive peptides increased with an increase in ripening time. Six of the identified ACEI peptides, Ile-Pro-Pro (IPP), Val-Pro-Pro (VPP), Glu-Lys-Asp-Glu-Arg-Phe (EKDERF), Val-Arg-TyrLeu (VRYL), Tyr-Pro-Phe-Pro-Gly-Pro-Ile-Pro-Asn (YPFPGPIPN), and Phe-Phe-Val-Ala-Pro (FFVAP), with known high ACEI activity (low $\mathrm{IC}_{50}$ values, the concentration needed to inhibit ACE to $50 \%$ of its original activity) were synthesized and used to quantify the amounts of these peptides in various cheese extracts. The concentrations of these 6 ACEI peptides increased up to a certain stage of ripening. The maximum contents of IPP, VPP, and EKDERF were 2.8, 7.4, and 5.3 $\mathrm{mg} / 100 \mathrm{~g}$ of cheese, respectively, and these levels were found in a 1-yr-old Cheddar cheese sample. The maximum content of VRYL $(7.5 \mathrm{mg} / 100 \mathrm{~g}$ of cheese) was found in a 2-yr-old Cheddar cheese sample, whereas the maximum content of YPFPGPIPN $(6.8 \mathrm{mg} / 100$ $\mathrm{g}$ of cheese) was found in a 6-mo-old Cheddar cheese sample. Trace amounts of FFVAP were found in these cheeses. Aged Cheddar cheese was found to be a rich source of ACEI peptides even though large differences exist between cheeses from different manufacturers.

Key words: angiotensin-I-converting enzymeinhibitory peptide, bioactive peptide, cheese ripening, proteolysis

Received March 13, 2015.

Accepted August 26, 2015.

${ }^{1}$ Corresponding author: jalucey@facstaff.wisc.edu
INTRODUCTION

Proteolysis is the major biochemical event during the ripening of Cheddar cheese, starting with preliminary proteolysis, which includes the initial breakdown of the caseins through the action of coagulants, such as rennet, as well as indigenous proteinases, such as plasmin and cathepsin D in milk (Fox, 1989). Secondary proteolysis is performed through the action of proteases and peptidases, such as cell wall-associated proteinases, from starter and nonstarter bacteria. Some of these peptides show biological activity, including hormoneor drug-like properties that eventually modulate physiological functions, and they are called bioactive peptides (Fitzgerald and Murray, 2006). Various types of bioactive peptides have been found in fermented dairy products, with potential properties such as antihypertensive, angiotensin-I-converting enzyme (ACE)inhibitory, immunomodulatory, antimicrobial, mineral transport, and opiate activities (Fitzgerald and Meisel, 2003; Silva and Malcata, 2005; Korhonen, 2009).

Angiotensin-I-converting enzyme is a peptidyldipeptide hydrolase that plays an important role in the regulation of hypertension. It increases blood pressure by converting angiotensin I to angiotensin II, a vasoconstrictor, and degrading bradykinin, a vasodilator. By inhibiting these processes, ACE inhibitors have antihypertensive effects (Seppo et al., 2003). Angiotensin-I-converting enzyme-inhibitory (ACEI) peptides have been detected in fermented milk products, including sour milk and cheese (Nakamura et al., 1995a; Hernandez-Ledesma et al., 2005; Bütikofer et al., 2008; Sieber et al., 2010). Sour milk fermented with various strains of Lactobacillus helveticus contained the tripeptides IPP and VPP, 2 well-known ACEI peptides, and they exhibited an antihypertensive effect by lowering the systolic blood pressure of mildly hypertensive human subjects (Seppo et al., 2002, 2003; Mizushima et al., 2004; Aihara et al., 2005). The analysis of watersoluble extracts (WSE) of different cheese varieties, such as blue, Camembert, Edam, Emmental, Gouda, Manchego, and Havarti, indicated a possible blood pressure-lowering effect in spontaneously hypertensive 
rats (SHR; Saito et al., 2000; Sipola et al., 2001, 2002; Gómez-Ruiz et al., 2002, 2004). Fractions of WSE from Cheddar cheese with high ACEI activity have been collected and a wide range of ACEI peptides, such as $\alpha_{\mathrm{S} 1}-\mathrm{CN}$ (f1-6), $\alpha_{\mathrm{S} 1}-\mathrm{CN}$ (f1-7), $\alpha_{\mathrm{S} 1}-\mathrm{CN}$ (f1-9), $\alpha_{\mathrm{S} 1}-\mathrm{CN}$ (f24-32), $\alpha_{\mathrm{S} 1}-\mathrm{CN}$ (f102-110), $\beta-\mathrm{CN}$ (f47-52), $\beta-\mathrm{CN}$ (f193-209), and к-CN (f96-102) have been identified (Stepaniak et al., 2001; Ong et al., 2007; Ong and Shah, 2008a). Ong et al. (2007) and Ong and Shah (2008a) reported relative concentrations of ACEI peptides in the WSE of Cheddar cheese but no true quantitative study has been done on the specific ACEI peptides found in Cheddar cheese.

The objective of this study was to determine the types and amounts of ACEI peptides produced during a 2-yr ripening period for commercial Cheddar cheeses. The influence of cheese ripening on the ACEI activity of the WSE of these commercial cheeses was evaluated. This was viewed as a baseline study to understand what types of peptides and amount of ACEI activity is present in existing commercial cheeses, before making any process changes to enhance ACEI activity. Although some types of ACEI peptides have been identified in Cheddar cheese, prior studies specifically enriched these peptides by methods such as use of enzyme-modified cheese or addition of selected probiotic cultures (Cliffe and Law, 1990; Ong et al., 2007; Ong and Shah, 2008a; Pritchard et al., 2010).

\section{MATERIALS AND METHODS}

\section{Commercial Cheddar Cheese Produced in Wisconsin}

Twelve Cheddar cheeses with different ripening times were kindly provided by 2 Wisconsin Cheddar cheese manufacturers (brand A and brand B). Both manufacturers were large cheese producers located in Wisconsin and they made cheese that is routinely aged for up to $2 \mathrm{yr}$.

\section{Preparation of WSE}

The WSE of Cheddar cheeses were prepared according to the method of Bütikofer et al. (2008) with some modifications. Fifteen grams of each ground cheese sample was homogenized with $30 \mathrm{~mL}$ of deionized (DI) water at 17,500 rpm for $15 \mathrm{~s}$ using an Ultra-Turrax T 25 basic homogenizer (IKA Works Inc., Wilmington, NC). The homogenized sample was incubated at $40^{\circ} \mathrm{C}$ for 60 min with stirring, before centrifugation at $8,000 \times g$ for $45 \mathrm{~min}$ at $4^{\circ} \mathrm{C}$. The water-soluble fraction between the upper layer of fat and the lower layer of sediment was collected. The WSE was filtered through Whatman filter paper (Whatman \#541) before fractionation by
UF using membranes with nominal molecular weight limits (NMWL) of 3,000 and 1,000 Da. The UF was performed using a stirred cell unit (Millipore Corporation, Billerica, MA) under a pressure of $\sim 276 \mathrm{kPa}$ supplied by a compressed nitrogen gas cylinder.

Fractions with molecular weight $(\mathbf{M W})<3,000 \mathrm{Da}$ were permeates of UF using the 3,000 Da NMWL membrane. These fractions were used for the ACE inhibitory test. Fractions with MW $<1,000$ Da were permeates of UF using 1,000 Da NMWL membrane. These fractions were used for HPLC-tandem mass spectrometry (MS/ MS) analysis. Fractions with MW higher than 1,000 but less than 3,000 Da $(1,000 \mathrm{Da}<\mathrm{MW}<3,000 \mathrm{Da})$ were prepared by first collecting permeate from the 3,000 Da NMWL membrane, and then ultrafiltering this permeate using the 1,000 Da NMWL membranes and collecting the retentate. These fractions were also used for HPLC-MS/MS analysis. Fractions with MW $<3,000 \mathrm{Da}$ was freeze-dried and stored at $-20^{\circ} \mathrm{C}$ until further analysis (ACE-inhibitory activity test). Fractions with $\mathrm{MW}<1,000 \mathrm{Da}$ was stored at $-20^{\circ} \mathrm{C}$ until further analysis. Fractions with 1,000 Da $<\mathrm{MW}<3,000$ Da were washed 2 times using $500 \mu \mathrm{L}$ of DI water each time and the solutions were collected and stored at $-20^{\circ} \mathrm{C}$ until further analysis (HPLC-MS/MS).

\section{Peptide Identification by HPLC-MS/MS}

The HPLC-MS/MS technique has previously been used for identification of cheese peptides (Gagnaire et al., 2001; Hernandez-Ledesma et al., 2004; Dupas et al., 2009). The UF fractions with MW $<1,000 \mathrm{Da}$ and 1,000 $\mathrm{Da}<\mathrm{MW}<3,000 \mathrm{Da}$ from the various aged cheeses were subjected to HPLC-MS/MS to separate and identify the peptides presented in these fractions. Peptide sequences were identified based on the fragments detected from MS/MS. The UF fractions were analyzed for peptides by nano-liquid chromatography-MS/MS using the Agilent 1100 LC/MSD Trap SL spectrometer (Agilent, Palo Alto, CA) with nano electrospray ionization. A $20-\mu \mathrm{L}$ aliquot of solution of each fraction was loaded onto a trap column (Zorbax $300 \mathrm{SB}^{-\mathrm{C}_{18}}, 5 \mu \mathrm{m}$, $5 \times 0.3 \mathrm{~mm}$, Agilent) and separation column (Zorbax $300 \mathrm{SB}^{-} \mathrm{C}_{18}, 3.5 \mu \mathrm{m}, 0.075 \times 150 \mathrm{~mm}$, Agilent). A 3-step gradient elution was performed at $0.22 \mu \mathrm{L} / \mathrm{min}$ for the first step: $5 \%$ solvent B (95\% acetonitrile, $0.1 \%$ formic acid) in solvent $\mathrm{A}$ ( $0.1 \%$ formic acid in water) to $45 \%$ solvent B over 115 min; second step: $45 \%$ solvent B to $65 \%$ solvent B over $20 \mathrm{~min}$; and third step: $65 \%$ solvent B to $100 \%$ solvent B over $5 \mathrm{~min}$. The MS/MS spectra were collected from 300 to $2,200 \mathrm{~m} / z$. Peptides were identified using the no-enzyme search of Bovine Taurus NCBInr amino acid sequence database (http://blast.ncbi.nlm. nih.gov/blast/Blast.cgi?PROGRAM=blastp\&PAGE_ 
TYPE $=$ BlastSearch\&LINK_LOC=blasthome) $\quad$ and Mascot search engine (Matrix Science, London, UK).

\section{Peptide Identification Using HPLC-Electrospray Ionization-Time-of-Flight MS}

Because of the detection limit of $500 \mathrm{Da}$ for the MS/MS method, the UF fractions with MW $<1,000$ Da from different aged cheeses were also subjected to HPLC-electrospray ionization (ESI)-time-of-flight (TOF)-MS to help identify these peptides (Martin et al., 2008). Peptides in the fractions of $\mathrm{MW}<1,000 \mathrm{Da}$ were identified based on theoretical molar mass of the selected peptides, the detected mass, and elemental composition analysis.

The fractions of MW $<1,000$ Da were subjected to HPLC-ESI-TOF MS using a Vydac- $\mathrm{C}_{8}$ column (3 $\mu \mathrm{m}, 2.1 \times 250 \mathrm{~mm})$ on an Agilent $1200 \mathrm{HPLC}$ connected to an Agilent LC/MSD TOF mass spectrometer (Agilent) with electrospray ionization in positive ion mode. Forty microliters of each fraction was injected. A linear gradient elution was performed at a flow rate of $0.25 \mathrm{~mL} / \mathrm{min}$ with $98 \%$ DI water, $2 \%$ acetonitrile, and $0.1 \%$ formic acid to $90 \%$ acetonitrile, $10 \%$ DI water, and $0.1 \%$ formic acid over $25 \mathrm{~min}$. The lists of peptide masses were generated in Agilent MassHunter Qualitative Analysis using the Find Compound by Molecular Feature. Features were restricted to $m / z 200$ to 3,000 with no charge state limitation over the retention time of 3.1 to 15.5 min when peaks were eluted by the gradient. Peptides were identified by mass and elemental composition analysis.

\section{Quantitative Analysis of ACE-Inhibitory Peptides}

High-performance liquid chromatography MS has been used for quantitative analysis of peptides (Bütikofer et al., 2008). Six ACEI peptides (Table 1) with high ACEI activity (low $\mathbf{I C}_{50}$ value; the concentration needed to inhibit ACE to $50 \%$ of its original activity) were synthesized using an automated peptide synthesizer, Symphony Quartet (Protein Technologies
Inc., Tucson, AZ), at the Biotechnology Center of the University of Wisconsin-Madison and were used as standards for the confirmation and quantitative analysis using LC-quadrupole-ion trap MS/MS. These ACEI peptides were Ile-Pro-Pro (IPP), Val-Pro-Pro (VPP), Glu-Lys-Asp-Glu-Arg-Phe (EKDERF), Val-Arg-TyrLeu (VRYL), Tyr-Pro-Phe-Pro-Gly-Pro-Ile-Pro-Asn (YPFPGPIPN), and Phe-Phe-Val-Ala-Pro (FFVAP). The synthesized peptides were diluted 10-fold with DI water and the standards were mixed and diluted to concentrations of $10.0,2.0,1.0,0.5,0.2$, and $0.1 \mu \mathrm{g} /$ $\mathrm{mL}$ with DI water. The MW $<1,000 \mathrm{Da}$ fractions and standards were analyzed on a Phenomenex Luna $\mathrm{C}_{18}$ $(150 \times 2 \mathrm{~mm}, 3 \mu \mathrm{m})$ column with an Agilent $1100 \mathrm{LC}$ (Agilent) connected to an Applied Biosystems 3200 Q TRAP LC/MS/MS System (Applied Biosystems, Foster City, CA) with Analyst 1.4.2 software. The column temperature was maintained at $45^{\circ} \mathrm{C}$. The mobile phase consisted of $0.1 \%$ formic acid in DI water (A) and $0.1 \%$ formic acid in acetonitrile (B) with a flow rate of 0.2 $\mathrm{mL} / \mathrm{min}$. Gradient elution was performed with $2 \%$ solvent $\mathrm{B}$ for the first $2 \mathrm{~min}$ and then increased linearly to $70 \%$ solvent B over $25 \mathrm{~min}$. The column was flushed with $95 \%$ solvent B and re-equilibrated for a minimum of $15 \mathrm{~min}$. The samples and standards were maintained at $5^{\circ} \mathrm{C}$, and $5 \mu \mathrm{L}$ was injected onto the column. The Qtrap parameters were as follows: curtain gas, $207 \mathrm{kPa}$; CAD medium; ion spray voltage, 5,500 V; temperature, $200^{\circ} \mathrm{C}$; ion source gas- $1,138 \mathrm{kPa}$; ion source gas-2, 138 $\mathrm{kPa}$; declustering potential, $10 \mathrm{~V}$; entrance potential, $10 \mathrm{~V}$; collision energy, $20 \mathrm{~V}$ and collision energy spread, $3 \mathrm{~V}$. A 6-point calibration was created with the peptide standards via the following MRM channels [precursor ion $(\mathrm{amu}) /$ product ion (amu)]: IPP (326.20/213.20), VPP (312.20/213.20), VRYL (275.70/451.20), EKDERF (412.20/566.20), FFVAP (580.30/295.10), and YPFPGPIPN (501.30/230.20).

\section{ACEI Activity Test}

The ACEI activity of WSE was measured according to the method of Cushman and Cheung (1971) with

Table 1. Angiotensin-I-converting enzyme (ACE)-inhibitory peptides selected for synthesis with their reported $\mathrm{IC}_{50}$ values $^{1}$

\begin{tabular}{llrl}
\hline Peptide & Possible source & $\begin{array}{r}\mathrm{IC}_{50} \\
(\mu M)\end{array}$ & Reference \\
\hline IPP & $\beta-\mathrm{CN}(\mathrm{f} 74-76) / \kappa-\mathrm{CN}(\mathrm{f} 108-110)$ & 5.0 & Nakamura et al. (1995b) \\
FFVAP & $\alpha_{S 1}-\mathrm{CN}(\mathrm{f} 23-27)$ & 6.0 & Maruyama et al. (1987a) \\
VPP & $\beta-\mathrm{CN}(\mathrm{f} 84-86)$ & 9.0 & Nakamura et al. (1995b) \\
EKDERF & $\kappa-\mathrm{CN}(\mathrm{f} 12-17)$ & 14.3 & Schlothauer et al. (1999) \\
YPFPGPIPN & $\beta-\mathrm{CN}(\mathrm{f} 60-68)$ & 14.8 & Saito et al. (2000) \\
VRYL & $\alpha_{S 2}$ CN (f204-207) & 24.1 & Gómez-Ruiz et al. (2004) \\
\hline
\end{tabular}

${ }^{1} \mathrm{IC}_{50}=$ concentration needed to inhibit ACE to $50 \%$ of its original activity. 
modifications as described by Nakamura et al. (1995b), Donkor et al. (2005), and Ong et al. (2007). This method is based on the liberation of hippuric acid from hippuryl-histidyl-leucine (HHL) catalyzed by ACE. Fifteen milligrams of freeze-dried UF permeate with MW $<3,000$ Da was dissolved in $1.0 \mathrm{~mL}$ of DI water. Then, HHL (Sigma, St. Louis, MO) was dissolved in $0.1 M$ sodium borate buffer $(\mathrm{pH} 8.3)$ containing 0.3 $M \mathrm{NaCl}$. Two hundred microliters of $5 \mathrm{~m} M$ HHL solution was mixed with $35 \mu \mathrm{L}$ of the sample solution and incubated at $37^{\circ} \mathrm{C}$ for $5 \mathrm{~min}$. The reaction was initiated by addition of $20 \mu \mathrm{L}$ of ACE solution (dissolved in DI water, $0.1 \mathrm{U} / \mathrm{mL}$ ). After $30 \mathrm{~min}$ of incubation at $37^{\circ} \mathrm{C}$, the reaction was stopped by addition of $250 \mu \mathrm{L}$ of $1 \mathrm{M} \mathrm{HCl}$. The hippuric acid liberated by ACE was extracted with $1.7 \mathrm{~mL}$ of ethyl acetate using vortex mixing for $15 \mathrm{~s}$. After centrifugation at $729 \times g$ for 10 min at room temperature, $1.4 \mathrm{~mL}$ of the organic phase was transferred into a fresh test tube and evaporated to dryness in a water bath for $15 \mathrm{~min}$ at $100^{\circ} \mathrm{C}$. The hippuric acid was redissolved in $1.0 \mathrm{~mL}$ of DI water and the absorbance at $228 \mathrm{~nm}$ was measured using a Shimadzu UV-Visible spectrophotometer (Shimadzu UV-1601 PC, Shimadzu Corp., Kyoto, Japan). The percentage of ACE inhibition was calculated according to the equation of Donkor et al. (2005). The ACE activity was measured as the amount catalyzing the formation of $1 \mu \mathrm{mol}$ of hippuric acid from HHL in 1 min at $37^{\circ} \mathrm{C}$ (Cushman and Cheung, 1971). The $\mathrm{IC}_{50}$ values were calculated as a concentration of the cheese WSE required to inhibit $50 \%$ of ACE activity (Ong et al., 2007).

\section{Statistical Analysis}

Quantitative analysis and ACE-inhibitory experiments were done in triplicate. Statistical analysis was performed using the Statgraphics program, version 5.1 plus (Manugistics, Rockville, MD). One-way ANOVA was performed to determine significant differences between peptide concentrations and $\mathrm{IC}_{50}$ values $(P<$ $0.05)$.

\section{RESULTS AND DISCUSSION}

\section{ACEI Peptides in Cheddar Cheese at Different Ripening Times}

In this study, we identified many ACEI peptides in commercial Cheddar cheeses manufactured in Wisconsin. The number of ACEI peptides detected changed with ripening time and in cheeses made by different manufacturers. Peptides that have previously been reported to have ACEI activity were identified in the UF fractions of cheeses. A summary of these ACEI peptides is shown in Table 2. Thirty-nine different types of ACEI peptides were found in these cheese samples, including 10 ACEI peptides derived from $\alpha_{\mathrm{S}_{1}} \mathrm{CN}, 2$ from $\alpha_{\mathrm{S}^{-}}$ $\mathrm{CN}, 15$ from $\beta$-CN, 4 from $\kappa$-CN, 3 from $\alpha$-LA, 4 from $\beta-\mathrm{LG}$, and 1 from BSA. The specific types of these ACEI peptides observed in a cheese sample varied depending on the manufacturer and the age of the sample (Figure 1). Differences in the types of ACEI peptides found in cheeses from the 2 different manufacturers was probably related to specific manufacturing practices, such as starter culture strains used (Fox et al., 1994), and this variability is in agreement with the trend from prior studies on other cheese types (Bütikofer et al., 2008). Their nonstarter lactic acid bacteria (NSLAB) flora is also likely to be different. It has been previously reported that the dominant strains of NSLAB in Cheddar cheese can vary between factories (Crow et al., 2002).

Similar numbers of ACEI peptides were found in brand $\mathrm{B}$ cheeses over a ripening period of $2 \mathrm{yr}$, whereas for brand $\mathrm{A}$, the trend was for an increase in the number of different ACEI peptides detected with increasing cheese age. Some of the ACEI peptides such as IPP, VPP, EKDERF, YPFPGPIHN, VRYL, YQEPVLGPVR, LAHKAL, and IR/RL were present in all the cheeses, including those at 3 to $6 \mathrm{~d}$ of age up to $2 \mathrm{yr}$ of age, whereas the other observed ACEI peptides were detected only in cheeses of a certain age.

\section{ACEI Activity of Cheddar Cheese of Different Ages}

The overall ACEI activity of WSE fractions of Cheddar cheeses with MW $<3,000 \mathrm{Da}$ is shown in Table 3. The $\mathrm{IC}_{50}$ values of WSE from the Cheddar cheeses decreased (i.e., exhibited greater ACEI activity) with an increase in ripening time (Table 2), which in agreement with the results of Ong et al. (2007) and Ong and Shah (2008a,b). Compared with young (3-6 d) cheeses, a significant decrease $(P<0.05)$ in ACE activity was observed in both of the 2-mo-old cheeses (Table 3). We detected no significant differences in ACE activity in cheeses during the ripening time of $60 \mathrm{~d}$ to $2 \mathrm{yr}$, except for the 1- and 2-yr-old cheeses from brand A (Table 3). The 1-yr-old cheese from brand A showed the lowest ACE activity but by 2 yr of age, its ACE activity had increased, possibly due to further breakdown of key ACEI peptides.

\section{Quantitative Analysis of Selected ACEI Peptides}

Six ACEI peptides (IPP, VPP, VRYL, FFVAP, EKDERF, and YPFPGPIPN) were chemically synthesized and used as standards for quantitative analysis of 


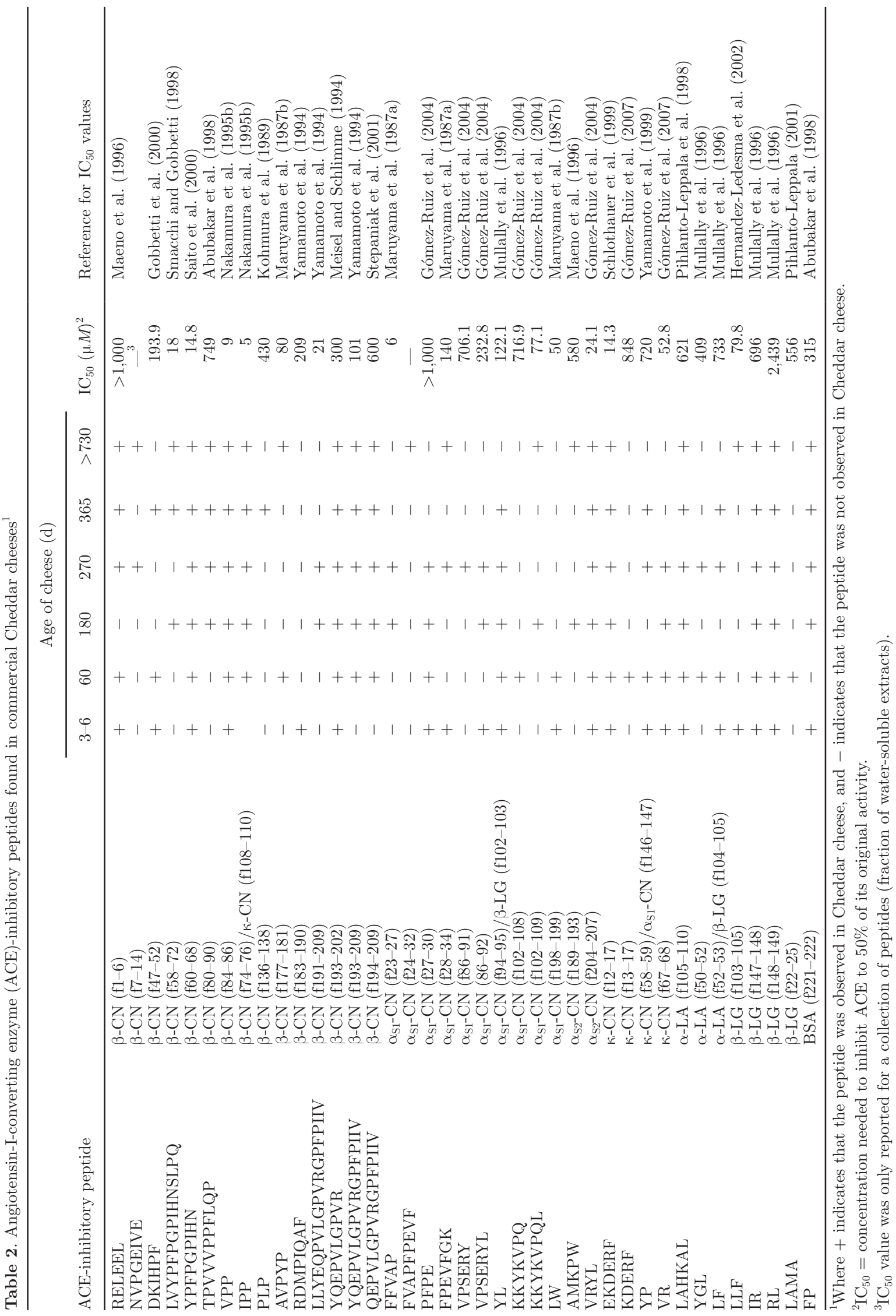


Table 3. Experimental $\mathrm{IC}_{50}$ values ${ }^{1}$ of water-soluble extract $\leq 3,000$ Da fractions from commercial Cheddar cheeses of different ages

\begin{tabular}{lrr}
\hline & \multicolumn{2}{c}{$\mathrm{IC}_{50}(\mathrm{mg} / \mathrm{mL})$} \\
\cline { 2 - 3 } Age $(\mathrm{d})$ & Brand A & Brand B \\
\hline $3-6$ & $11.4^{\mathrm{a}, \mathrm{A}}$ & $11.9^{\mathrm{a}, \mathrm{A}}$ \\
60 & $8.4^{\mathrm{b}, \mathrm{C}}$ & $8.6^{\mathrm{b}, \mathrm{B}}$ \\
180 & $8.8^{\mathrm{b}, \mathrm{C}}$ & $8.5^{\mathrm{b}, \mathrm{B}}$ \\
270 & $9.0^{\mathrm{b}, \mathrm{C}}$ & $8.1^{\mathrm{b}, \mathrm{B}}$ \\
365 & $7.6^{\mathrm{c}, \mathrm{D}}$ & $8.3^{\mathrm{b}, \mathrm{B}}$ \\
$>730$ & $10.4^{\mathrm{d}, \mathrm{B}}$ & $8.2^{\mathrm{b}, \mathrm{B}}$ \\
\hline
\end{tabular}

${ }^{\mathrm{a}-\mathrm{d}}$ Means within a column not sharing a common lowercase superscript differ $(P<0.05$; comparing the effect of ripening time for a single brand).

${ }^{\mathrm{A}-\mathrm{D}}$ Means within a row not sharing a common uppercase superscript differ $(P<0.05$; comparing the effect of brand for a single ripening time).

${ }^{1} \mathrm{IC}_{50}=$ concentration needed to inhibit ACE to $50 \%$ of its original activity. Values represent the means of triplicates.

these peptides in cheese (Table 1). The concentrations of these selected ACEI peptides in Cheddar cheeses with different ripening times are shown in Figures 2 and 3. Trace amounts of FFVAP were found in Cheddar cheese (Figure 3). High amounts of the other 5 synthesized ACEI peptides, especially the tripeptides IPP and VPP, were found in all Cheddar cheeses.

These results confirmed the presence of considerable amounts of IPP and VPP in Cheddar cheese, with their concentrations tending to increase with an increase in ripening time (Figure 2). Significantly higher amounts $(P<0.05)$ of IPP and VPP contents were found in brand A Cheddar cheeses compared with brand B cheeses. The maximum concentrations of these 2 tripeptides, IPP $(2.8 \mathrm{mg} / 100 \mathrm{~g}$ of cheese) and VPP (7.4 $\mathrm{mg} / 100 \mathrm{~g}$ of cheese), were found in the 1-yr-old brand A Cheddar cheese.

The peptides IPP and VPP were first reported by Nakamura et al. (1995b) as key ACEI peptides with high ACEI activities of $\mathrm{IC}_{50}=5.0$ and $9.0 \mu \mathrm{M}$, respectively. They were also found to have significant antihypertensive effects in SHR (Nakamura et al., 1995b). The peptides IPP and VPP both have the C-terminal Pro-Pro sequence, which is believed to be resistant to further digestion by peptidases (Kitts and Weiler, 2003). Therefore, IPP and VPP may be effectively absorbed in the small intestine following oral ingestion and thus are available to exert an antihypertensive effect. In vivo studies have shown that oral administration of dairy products containing high levels of IPP $(0.3 \mathrm{mg} / \mathrm{kg}$ of $\mathrm{BW})$ and VPP $(0.6 \mathrm{mg} / \mathrm{kg}$ of BW) had antihypertensive effects in SHR (Nakamura et al., 1995a, 1996; Masuda et al., 1996; Sipola et al., 2001, 2002). Clinical studies have shown that administration of fermented milk products containing IPP at a dosage of 1.1 to 4.7 $\mathrm{mg} / \mathrm{d}$ and VPP at a dosage of 1.15 to $8.3 \mathrm{mg} / \mathrm{d}$ can

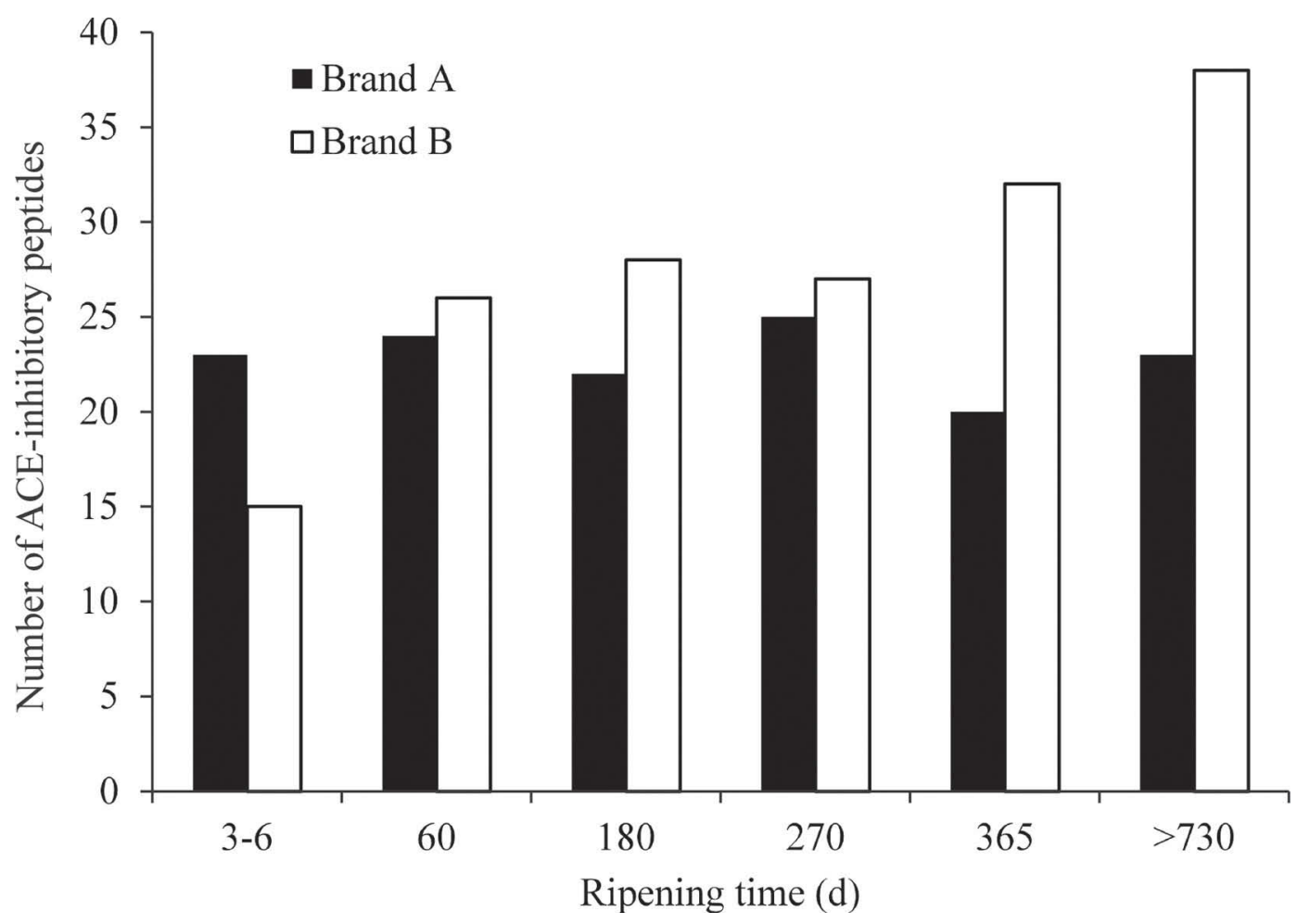

Figure 1. Number of angiotensin-I-converting enzyme (ACE)-inhibitory peptides in Cheddar cheeses of different ripening times. 


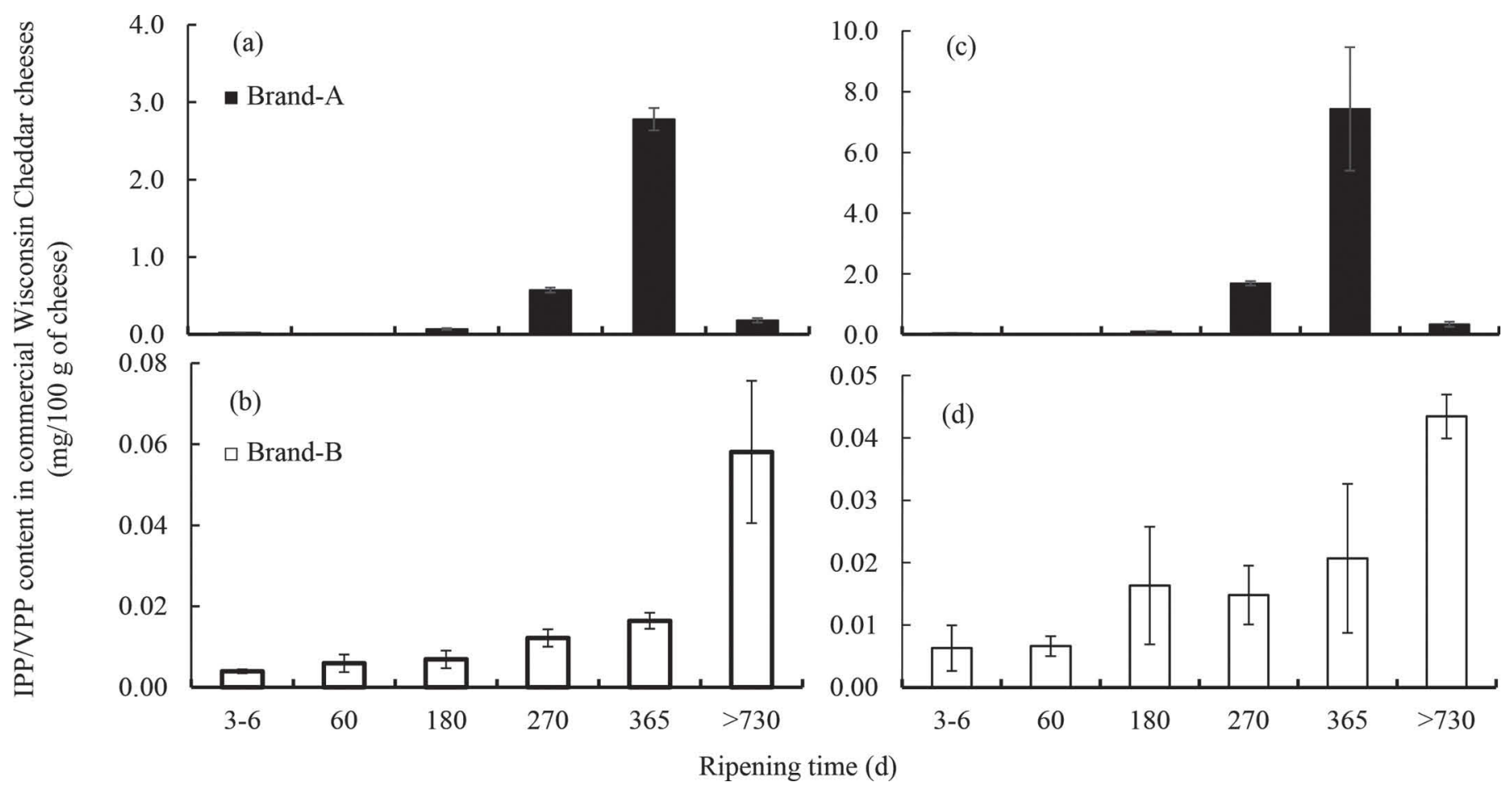

Figure 2. Contents of the tripeptides IPP $(\mathrm{a}, \mathrm{b})$ and VPP $(\mathrm{c}, \mathrm{d})$ in Wisconsin Cheddar cheeses of different ages $(\mathrm{n}=3$, error bars indicate standard deviation).

significantly decrease blood pressure in subjects with mild hypertension or high-normal blood pressure (Hata et al., 1996; Mizushima et al., 2004; Aihara et al., 2005; Foltz et al., 2007).

If IPP and VPP do indeed have in vivo antihypertensive effects, then based on the concentrations of these 2 tripeptides present in Cheddar cheeses, we would expect to observe an antihypertensive effect if $100 \mathrm{~g}$ of the 1-yr-old brand A Cheddar cheese were consumed by subjects exhibiting mild or high blood pressure.

There is limited quantitative information in other cheese varieties about the content of key ACEI peptides such as IPP and VPP. Bütikofer et al. (2008) studied various cheeses from Switzerland and found that the IPP contents were $\sim 2$ to $79 \mathrm{mg} / \mathrm{kg}$ (semihard type cheeses) and $\sim 1$ to $98 \mathrm{mg} / \mathrm{kg}$ (extra hard cheeses), whereas VPP contents were $\sim 5$ to $238 \mathrm{mg} / \mathrm{kg}$ (semihard type cheeses) and $\sim 1$ to $333 \mathrm{mg} / \mathrm{kg}$ (extra hard cheese). Our results showed that the maximum IPP and VPP contents in Cheddar cheese samples were 28 and $74 \mathrm{mg} / \mathrm{kg}$, respectively, which were within the ranges observed by Bütikofer et al. (2008). Meyer et al. (2009) suggested that concentrations of VPP and IPP above $100 \mathrm{mg} / \mathrm{kg}$ are attainable in Swiss cheeses.

We observed high amounts of VRYL in both Cheddar cheeses and observed a trend for an increasing concentration of VRYL with age in brand B cheeses (Figure 3). A similar trend was found in brand A cheeses but only during the aging period from 3 to $6 \mathrm{~d}$ to 6 mo. The maximum content of VRYL was $7.5 \mathrm{mg} / 100 \mathrm{~g}$ of cheese and it was obtained in the 2-yr-old brand B Cheddar cheese.

The ACEI peptide EKDERF was found in both brands of Cheddar cheeses and its concentration increased with ripening time from 3 to $6 \mathrm{~d}$ to $6 \mathrm{mo}$ (Figure 3). For brand A cheese, EKDERF content increased with ripening time up to 6 mo but decreased with longer ripening times, such as 9 mo to 2 yr. For brand $\mathrm{B}$ cheeses, an increasing trend was observed in the concentration of EKDERF with aging time. The maximum content of EKDERF was $5.3 \mathrm{mg} / 100 \mathrm{~g}$ of cheese and it was found in the 1-yr-old brand B Cheddar. The peptide EKDERF, $\kappa-C N$ (f12-17), was first reported as being an ACEI peptide in a milk protein hydrolysate by Gómez-Ruiz et al. (2007). That group estimated its $\mathrm{IC}_{50}$ value as $14.3 \mu \mathrm{M}$. High concentrations of EKDERF were detected in our Cheddar cheese samples (Figure 3), which might explain, in part, why the WSE of the 1-yr-old brand $\mathrm{B}$ cheese showed low ACEI activity $\left(\mathrm{IC}_{50}=8.3 \mathrm{mg} / \mathrm{mL}\right.$; Table 3$)$.

The presence of a very small amount of FFVAP was found in brand B Cheddar cheese but was not detected in brand A cheese samples (Figure 3). The peptide FFVAP, $\alpha_{S 1}-\mathrm{CN}$ (f23-27), was first reported as an ACEI peptide by Maruyama et al. (1987a) in an enzymatic hydrolysate of casein; those authors estimated 


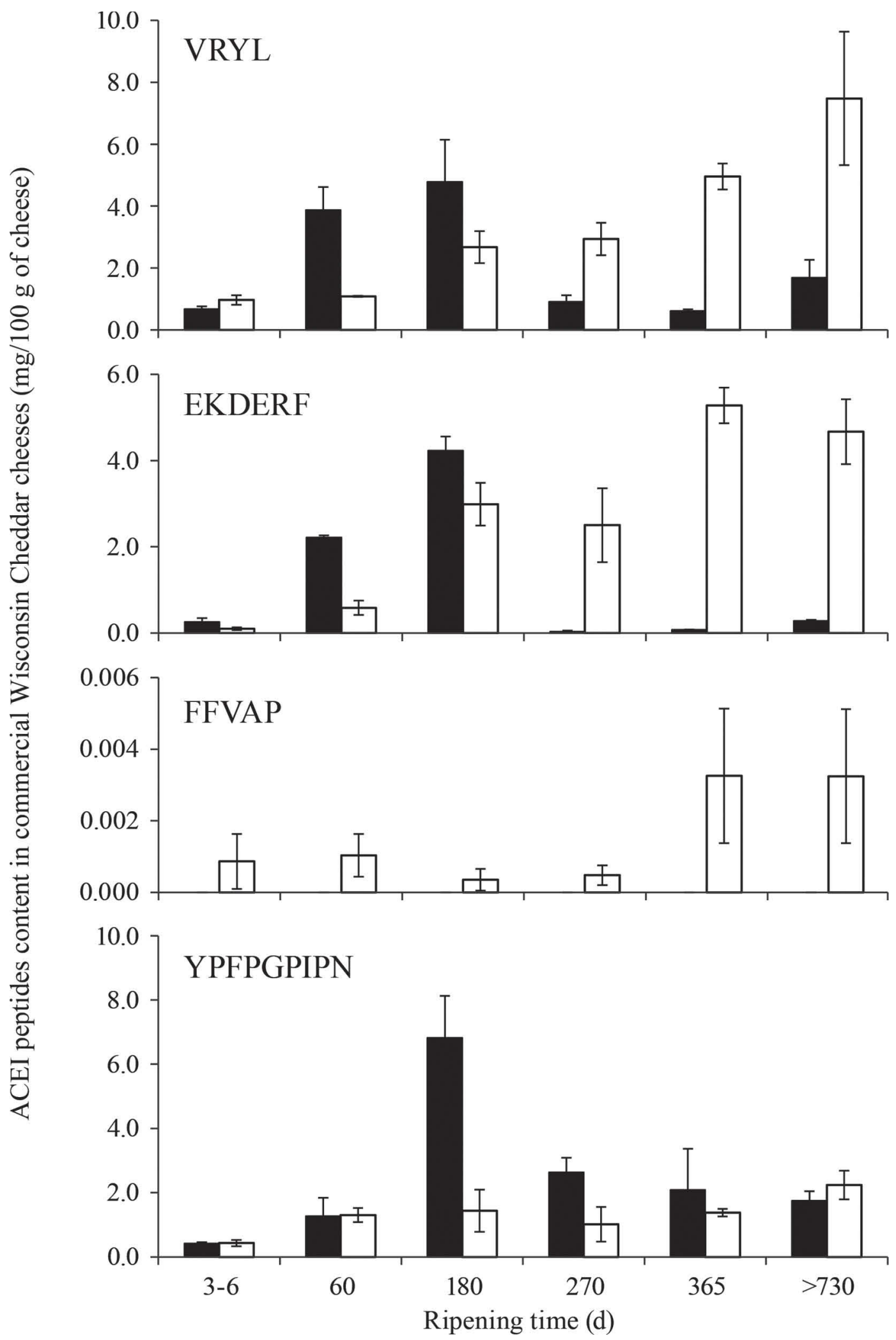

Figure 3. Contents of angiotensin-I-converting enzyme (ACE)-inhibitory peptides VRYL, EKDERF, FFVAP, and YPFPGPIPN in Wisconsin Cheddar cheeses (brand $\mathrm{A}, \mathbf{\square}$, and brand $\mathrm{B}, \square)$ of different ages ( $=3$, error bars indicate standard deviation). 
that it had high ACEI activity $\left(\mathrm{IC}_{50}=6.0 \mu M\right)$. In our investigation, this pentapeptide was found in Cheddar cheese, even though its concentration was low.

In this study, high concentrations of YPFPGPIPN were found in both Cheddar cheeses (Figure 3). The maximum content of YPFPGPIPN was $6.8 \mathrm{mg} / 100 \mathrm{~g}$ of cheese and it was detected in the 6-mo-old brand A Cheddar cheese. The peptide YPFPGPIPN, $\beta-C N$ (f60-68), was first reported by Saito et al. (2000) as an ACEI peptide obtained from an 8-mo-old Gouda cheese; they determined its $\mathrm{IC}_{50}$ value as $14.8 \mu \mathrm{M}$ and noted that it also showed an antihypertensive effect on SHR (Saito et al., 2000). In this study, we observed high amounts of YPFPGPIPN in both brands of Cheddar cheese (Figure 3).

The highest ACEI activity was observed in 1-yr-old brand A Cheddar cheese (i.e., lowest $\mathrm{IC}_{50}$ value; Table 3 ), which also had the highest concentrations of IPP $(2.8 \mathrm{mg} / 100 \mathrm{~g}$ of cheese) and VPP $(7.4 \mathrm{mg} / 100 \mathrm{~g}$ of cheese), and some VRYL (0.6 mg/100 g of cheese) and YPFPGPIPN (2.1 mg/100 g of cheese). The 1-yr-old brand B Cheddar also showed high ACEI activity, which was likely caused by its high concentrations of EKDERF (5.3 mg/100 g of cheese), VRYL (5.0 mg/100 $\mathrm{g}$ of cheese), and YPFPGPIPN (1.4 mg/100 $\mathrm{g}$ of cheese).

The 2-yr-old brand A Cheddar had lower concentrations of IPP $(0.2 \mathrm{mg} / 100 \mathrm{~g}$ of cheese), VPP (0.3 $\mathrm{mg} / 100 \mathrm{~g}$ of cheese), and YPFPGPIPN $(1.7 \mathrm{mg} / 100 \mathrm{~g}$ of cheese) compared with its 9-mo- and 1-yr-old cheeses. The concentrations of VRYL $(1.7 \mathrm{mg} / 100 \mathrm{~g}$ of cheese) and EKDERF $(0.3 \mathrm{mg} / 100 \mathrm{~g}$ of cheese) were also low. These results might explain why the 2-yr-old brand A cheese sample showed lower ACEI activity compared with the 2-mo-, 6-mo-, 9-mo-, and 1-yr-old brand A cheeses (Table 3). These results were consistent with the findings of Meisel et al. (1997), Ryhänen et al. (2001), Ong et al. (2007), and Ong and Shah (2008a,b), who found that ACEI activity was lower in cheese samples with a low degree of proteolysis (or during the early stage of ripening) and that activity generally increased as proteolysis proceeded up to a certain level but decreased again with more proteolysis, probably due to the further breakdown of ACEI peptides (Meyer et al., 2009).

\section{Possible Mechanisms Responsible for Creating ACEI Peptides}

Peptides with ACEI activity are generated by various enzymatic activities during cheese ripening. The possible enzymes responsible for generating the ACEI peptides identified in Cheddar cheeses are listed in Table 4. A large number of peptides, including ACEI peptides, are released as a result of proteolysis during cheese rip- ening (Rank et al., 1985; Fox, 1989; Sieber et al., 2010). Several enzymes are likely needed to produce a specific ACEI peptide (for both the $\mathrm{N}$ - and C-terminal cleavage sites). Most of the ACEI peptides were low in molar mass (i.e., $\leq 3,000 \mathrm{Da}$ ), which would likely have needed the action of bacterial cell wall-associated proteinase and several types of peptidases, which together may have contributed to the production of 18 different types of ACEI peptides during Cheddar cheese ripening. Some of the identified ACEI peptides might have been generated (partly) by the action of indigenous enzymes in milk, such as plasmin, cathepsins B, D, and G, and residual chymosin from cheese making (Table 4).

For the 6 key ACEI peptides that we investigated in detail in this study, the enzymes potentially involved in their formation are known for only some of them. It is still not clear which enzymes contribute to the production of IPP. It has been suggested that VPP might be created partly by the action of the indigenous proteinase in milk, cathepsin G (Upadhyay et al., 2004). The peptide FFVAP, $\alpha_{\mathrm{S}^{-}} \mathrm{CN}$ (f23-27), was probably created due to the action of plasmin cleaving at $\mathrm{Arg}_{22}-\mathrm{Phe}_{23}$ bond of $\alpha_{\mathrm{S} 1}$-CN (Fox et al., 1994) and possibly other enzymes, such as proteinases and peptidases from the lactic acid bacteria in cheese. The peptide YPFPGPIHN could be formed by hydrolysis of the peptide bond $\mathrm{Asn}_{68}-\mathrm{Ser}_{69}$ by cell wall-associated proteinase, as it has been reported that Lactococcus lactis ssp. cremoris strains AC1, SK112, and HP can cleave at $\mathrm{Asn}_{68}-\mathrm{Ser}_{69}$ (Fox et al., 1994), or by the action of cathepsin $\mathrm{B}$, which can cleave at $\mathrm{Val}_{59}-\mathrm{Tyr}_{60}$ (Upadhyay et al., 2004). The peptide YPFPGPIHN can be hydrolyzed by cell wall-associated peptidases and aminopeptidases into smaller peptides, which might explain the decrease in the concentration of YPFPGPIPN when cheese was aged more than 6 mo (Figure 3). It is not clear which enzymes contributed to the formation of EKDERF.

Some of the ACEI peptides can be further degraded to smaller, inactive fragments through ongoing proteolysis by proteinases and peptidases released by lactic acid bacteria during cheese ripening (Fox, 1989; Meisel et al., 1997). In some cases, an ACEI peptide can be further hydrolyzed to generate another type of bioactive peptide. For example, ACEI peptide YPFPGPI$\mathrm{HN}$, obtained from $\beta-\mathrm{CN}$ (f $60-68$ ), can be degraded by the cell-wall associated peptidase X-prolyl-dipeptidyl aminopeptidase (X-PDAP) from Lactococcus lactis ssp. cremoris into YP and FPGPIHN (Smid et al., 1991). The peptide FPGPIHN can be degraded by aminopeptidase $\mathrm{P}(\mathrm{PepP})$ to remove the $\mathrm{N}$-terminal amino acid and produce Phe and PGPIPN [ $\beta-\mathrm{CN}$ (f63-68); Upadhyay et al., 2004], which is an immunostimulating peptide (Migliore-Samour and Jollés, 1988). 


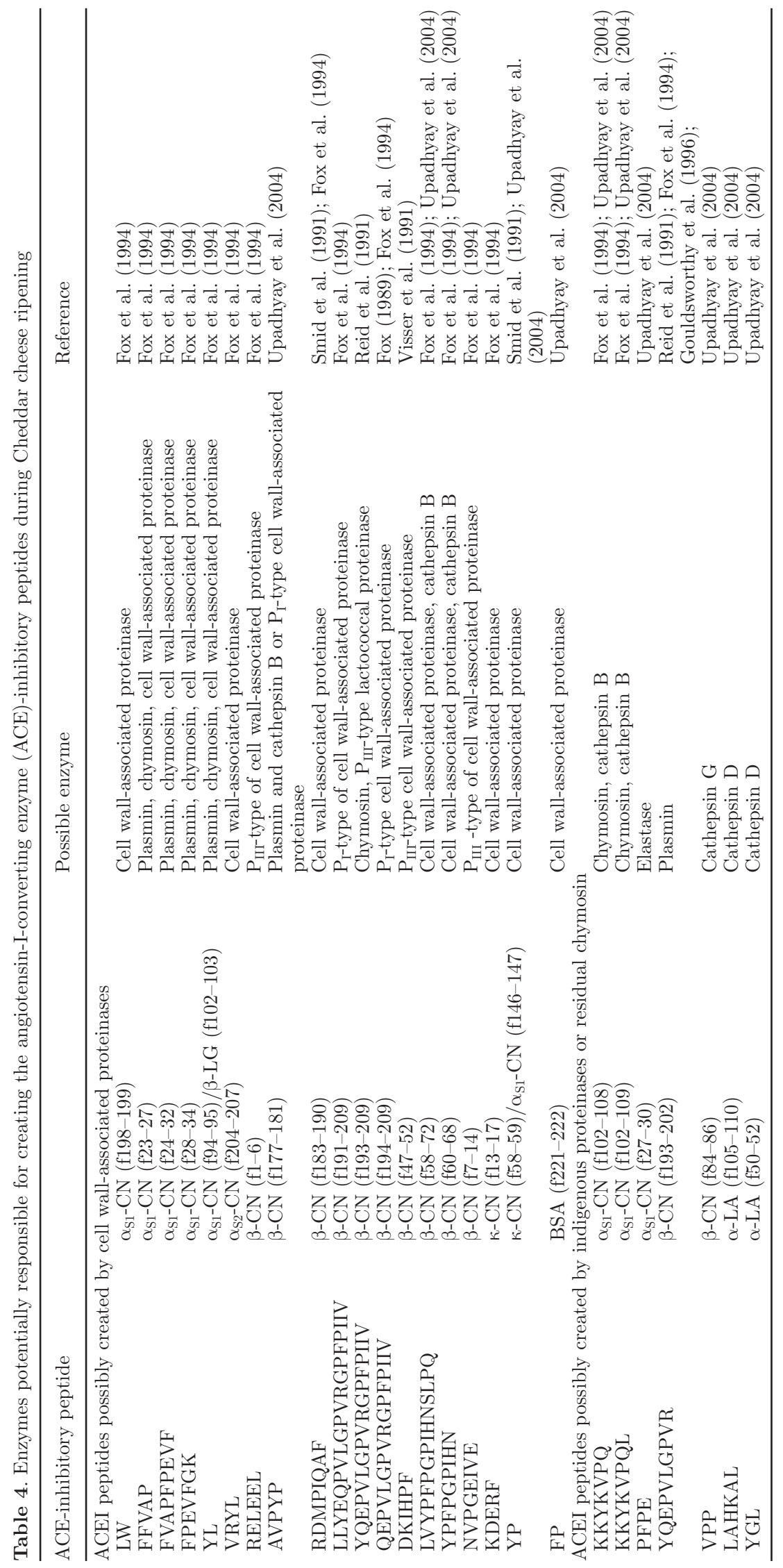


It is notable that some of the ACEI peptides, such as IPP, VPP, EKDERF, YPFPGPIHN, VRYL, YQEPVLGPVR, LAHKAL, and IR/RL, were present in all cheeses, within the range of ages examined, whereas other observed ACEI peptides were present only in cheeses of a specific age (Table 2).

\section{CONCLUSIONS}

Water-soluble extracts from 2 brands of commercial Cheddar cheeses made in Wisconsin showed that ACEI activity increased with an increase in ripening time. Many ACEI peptides were detected and identified in these cheeses and the types of ACEI peptides increased with age. We quantified 6 of the ACEI peptides-IPP, VPP, VRYL, FFVAP, EKDERF, and YPFPGPIPNand their concentrations increased up to certain level of ripening. We observed large differences in the types and concentrations of ACEI peptides between cheeses produced by the 2 cheese companies; presumably this reflects differences in manufacturing conditions, including type of starter cultures and the NSLAB microflora. Aged Cheddar cheese is a good source of ACEI peptides with high ACEI activity. In vivo studies will be necessary to validate the antihypertensive effects of these ACEI peptides obtained in Cheddar cheese.

\section{ACKNOWLEDGMENTS}

The authors thank the Biotechnology Center, University of Wisconsin-Madison, for use of the HPLCtandem mass spectrometers. The Wisconsin Milk Marketing Board (Madison, WI) is thanked for funding this project.

\section{REFERENCES}

Abubakar, A., T. Saito, H. Kitazawa, Y. Kawai, and T. Itoh. 1998. Structural analysis of new antihypertensive peptides derived from cheese whey protein by proteinase $\mathrm{K}$ digestion. J. Dairy Sci. 81:3131-3138.

Aihara, K., O. Kajimoto, H. Hirata, R. Takahashi, and Y. Nakamura. 2005. Effect of powdered fermented milk with Lactobacillus helveticus on subjects with high-normal blood pressure or mild hypertension. J. Am. Coll. Nutr. 24:257-265.

Bütikofer, U., J. Meyer, R. Sieber, B. Walther, and D. Wechsler. 2008. Occurrence of the angiotensin-converting enzyme-inhibiting tripeptides Val-Pro-Pro and Ile-Pro-Pro in different cheese varieties of Swiss origin. J. Dairy Sci. 91:29-38.

Cliffe, A. J., and B. A. Law. 1990. Peptide composition of enzymetreated Cheddar cheese slurries, determined by reverse phase high performance liquid chromatography. Food Chem. 36:73-80.

Crow, V., B. Curry, M. Christison, K. Hellier, R. Holland, and S.-Q. Liu. 2002. Raw milk flora and NSLAB as adjuncts. Aust. J. Dairy Technol. 57:99-105.

Cushman, D. W., and H. S. Cheung. 1971. Spectrophotometric assay and properties of the angiotensin-converting enzyme of rabbit lung. Biochem. Pharmacol. 20:1637-1648.
Donkor, O. N., A. Henriksson, T. Vasiljevic, and N. P. Shah. 2005. Probiotic strains as starter cultures improve angiotensin-converting enzyme inhibitory activity in soy yogurt. J. Food Sci. 70:375-381.

Dupas, C., I. Adt, A. Cottaz, R. Boutrou, D. Molle, J. Jardin, T. Jouvet, and P. Degaeve. 2009. A chromatographic procedure for semi-quantitative evaluation of caseinphosphopeptides in cheese. Dairy Sci. Technol. 89:519-529.

Fitzgerald, R., and B. A. Murray. 2006. Bioactive peptides and lactic fermentation. Int. J. Dairy Technol. 59:118-125.

Fitzgerald, R. J., and H. Meisel. 2003. Milk protein hydrolysates and bioactive peptides. Pages $675-698$ in Volume 1: Proteins. Advanced Dairy Chemistry. 3rd ed. Part B. P. F. Fox and P. L. H. McSweeney, ed. Kluwer Academic/Plenum Publishers, New York, NY.

Foltz, M., E. E. Meynen, V. Bianco, C. van Platerink, T. M. Koning, and J. Kloek. 2007. Angiotensin converting enzyme inhibitory peptides from a lactotripeptide-enriched milk beverage are absorbed intact into the circulation. J. Nutr. 137:953-958.

Fox, P. F. 1989. Proteolysis during cheese manufacture and ripening. J. Dairy Sci. 72:1379-1400.

Fox, P. F., T. K. Singh, and P. L. H. McSweeney. 1994. Proteolysis in cheese during ripening. Pages 1-23 in Biochemistry of Milk Products. A. T. Andrews and J. Varley, ed. The Royal Society of Chemistry, Cambridge, UK.

Gagnaire, V., D. Molle, M. Herouin, and J. Leonil. 2001. Peptides identification during Emmental cheese ripening: Origin and proteolytic systems involved. J. Agric. Food Chem. 49:4402-4413.

Gobbetti, M., P. Ferranti, E. Smacchi, F. Goffred, and F. Addeo. 2000. Production of angiotensin-I-converting-enzyme-inhibitory peptides in fermented milks started by Lactobacillus delbrueckii subsp. bulgaricus SS1 and Lactococcus lactis subsp. cremoris FT4. Appl. Environ. Microbiol. 66:3898-3904.

Gómez-Ruiz, J. A., M. Ramos, and I. Recio. 2002. Angiotensin-converting enzyme-inhibitory peptides in Manchego cheeses manufactured with different starter cultures. Int. Dairy J. 12:697-706.

Gómez-Ruiz, J. A., M. Ramos, and I. Recio. 2004. Angiotensin converting enzyme-inhibitory activity of peptides isolated from Manchego cheese. Stability under simulated gastrointestinal digestion. Int. Dairy J. 14:1075-1080.

Gómez-Ruiz, J. A., M. Ramos, and I. Recio. 2007. Identification of novel angiotensin-converting enzyme-inhibitory peptides from ovine milk proteins by CE-MS and chromatographic techniques. Electrophoresis 28:4202-4211.

Gouldsworthy, A. M., J. L. Leaver, and J. M. Banks. 1996. Application of a mass spectrometry sequencing technique for identifying peptides present in Cheddar cheese. Int. Dairy J. 6:781-790.

Hata, Y., M. Yamamoto, M. Ohni, K. Nakajima, and Y. Nakamura. 1996. A placebo-controlled study of the effect of sour milk on blood pressure in hypertensive subjects. Am. J. Clin. Nutr. 64:767-771.

Hernandez-Ledesma, B., L. Amigo, M. Ramos, and I. Recio. 2004. Application of high-performance liquid chromatography-tandem mass spectrometry to the identification of biologically active peptides produced by milk fermentation and stimulated gastrointestinal digestion. J. Chromatogr. A 1049:107-114.

Hernandez-Ledesma, B., B. Miralles, L. Amigo, M. Ramos, and I. Recio. 2005. Identification of antioxidant and ACE-inhibitory peptides in fermented milk. J. Sci. Food Agric. 85:1041-1048.

Hernandez-Ledesma, B., I. Recio, M. Ramos, and L. Amigo. 2002. Preparation of ovine and caprine $\beta$-lactoglobulin hydrolysates with ACE-inhibitory activity. Identification of active peptides from caprine $\beta$-lactoglobulin hydrolysates with thermolysin. Int. Dairy J. 12:805-812.

Kitts, D. D., and K. Weiler. 2003. Bioactive proteins and peptides from food sources. Applications of bioprocesses used in isolation and recovery. Curr. Pharm. Des. 9:1309-1323.

Kohmura, M., N. Nio, K. Kubo, Y. Minoshima, E. Munekata, and Y. Ariyosh. 1989. Inhibition of angiotensin-converting enzyme by synthetic peptides of human $\beta$-casein. Agric. Biol. Chem. 53:21072114.

Korhonen, H. 2009. Milk-derived bioactive peptides: From science to applications. J. Funct. Foods 1:177-187. 
Maeno, M., N. Yamamoto, and T. Takano. 1996. Identification of an antihypertensive peptide from casein hydrolysate produced by a proteinase from Lactobacillus helveticus CP790. J. Dairy Sci. 79:1316-1321.

Martin, M., A. Wellner, I. Ossowski, and T. Henile. 2008. Identification and quantification of inhibitors for angiotensin-converting enzyme in hypoallergenic infant milk formulas. J. Agric. Food Chem. 56:6333-6338.

Maruyama, S., H. Mitachi, J. Awaya, M. Kurono, N. Tomizuka, and H. Suzuki. 1987b. Angiotensin-I-converting enzyme inhibitory activity of the C-terminal hexapeptide of $\alpha_{\mathrm{s} 1}$-casein. Agric. Biol. Chem. 51:2557-2561.

Maruyama, S., H. Mitachi, H. Tanaka, N. Tomizuka, and H. Suzuki. 1987a. Studies on the active site and antihypertensive activity of angiotensin I-converting enzyme inhibitors derived from casein. Agric. Biol. Chem. 51:1581-1586.

Masuda, O., Y. Nakamura, and T. Takano. 1996. Antihypertensive peptides are present in aorta after oral administration of sour milk containing these peptides to spontaneously hypertensive rats. J. Nutr. 126:3063-3068.

Meisel, H., A. Goepfert, and S. Günther. 1997. ACE-inhibitory activities in milk products. Milchwissenschaft 52:307-311.

Meisel, H., and E. Schlimme. 1994. Inhibitors of angiotensin converting enzyme derived from bovine casein (casokinins). Pages 27-33 in $\beta$-Casomorpnins and Related Peptides: Recent Developments. V. Brantl and H. Teschemacher, ed. VCH Vsringsgesellschaft $\mathrm{mbH}$, Weinheim, Germany.

Meyer, J., U. Bütikofer, B. Walther, D. Wechsler, and R. Seiber. 2009. Changes in angiotensin-converting enzyme inhibition and concentrations of the tripeptides Val-Pro-Pro and Ile-Pro-Pro during ripening of different Swiss cheese varieties. J. Dairy Sci. 92:826-836.

Migliore-Samour, D., and P. Jollés. 1988. Casein, a prohormone with an immunomodulating role for the newborn? Experientia 44:188193.

Mizushima, S., K. Ohshige, J. Watanabe, M. Kimura, T. Kadowaki, Y. Nakamura, O. Tochikubo, and H. Ueshima. 2004. Randomized controlled trial of sour milk on blood pressure in borderline hypertensive men. Am. J. Hypertens. 17:701-706.

Mullally, M. M., H. Meisel, and R. J. FitzGerald. 1996. Synthetic peptides corresponding to $\alpha$-lactalbumin and $\beta$-lactoglobulin sequences with angiotensin-I-converting enzyme inhibitory activity. Biol. Chem. Hoppe Seyler 377:259-260.

Nakamura, Y., O. Masuda, and T. Takano. 1996. Decrease of tissue angiotensin-I-converting enzyme activity upon feeding sour milk in spontaneously hypertensive rats. Biosci. Biotechnol. Biochem. 60:488-489.

Nakamura, Y., N. Yamamoto, K. Sakai, A. Okubo, S. Yamazaki, and T. Takano. 1995b. Purification and characterization of angiotensin I-converting enzyme inhibitors from sour milk. J. Dairy Sci. 78:777-783.

Nakamura, Y., N. Yamamoto, K. Sakai, and T. Takano. 1995a. Antihypertensive effect of sour milk and peptides isolated from it that are inhibitors to angiotensin-I-converting enzyme. J. Dairy Sci. $78: 1253-1257$.

Ong, L., A. Henriksson, and N. Shah. 2007. Angiotensin converting enzyme-inhibitory activity in Cheddar cheeses made with the addition of probiotic Lactobacillus casei sp. Lait 87:149-165.

Ong, L., and N. P. Shah. 2008a. Release and identification of angiotensin-converting enzyme-inhibitory peptides as influenced by ripening temperatures and probiotic adjuncts in Cheddar cheeses. Food Sci. Technol. (Campinas.) 41:1555-1566.

Ong, L., and N. P. Shah. 2008b. Influence of probiotic Lactobacillus acidophilus and L. helveticus on proteolysis, organic acid profiles, and ACE-inhibitory activity of Cheddar cheeses ripened at 4, 8, and $12^{\circ} \mathrm{C}$. J. Food Sci. 73:M111-120.

Pihlanto-Leppala, A. 2001. Bioactive peptides derived from bovine whey proteins: opioid and ACE-inhibitory peptides. Trends Food Sci. Technol. 11:347-356.
Pihlanto-Leppala, A., T. Rokka, and H. Korhonen. 1998. AngiotensinI-converting enzyme inhibitory peptides derived from bovine milk proteins. Int. Dairy J. 8:325-331.

Pritchard, S. R., M. Phillips, and K. Kailasapathy. 2010. Identification of bioactive peptides in commercial Cheddar cheese. Food Res. Int. 43:1545-1548.

Rank, T. C., R. Grappin, and N. F. Olson. 1985. Secondary proteolysis of cheese during ripening: A review. J. Dairy Sci. 68:801-805.

Reid, J. R., C. H. Moore, G. G. Midwinter, and G. G. Prichard. 1991. Action of a cell wall proteinase from Lactococcus lactis ssp. cremoris SK11on bovine $\alpha_{\mathrm{s} 1}$-casein. Appl. Microbiol. Biotechnol. $35: 222-227$.

Ryhänen, E.-L., A. Pihlanto-Leppälä, and E. Pahkala. 2001. A new type of ripened, low-fat cheese with bioactive properties. Int. Dairy J. 11:441-447.

Saito, T., T. Nakamura, H. Kitazuwa, Y. Kawai, and T. Itoh. 2000. Isolation and structural analysis of antihypertensive peptides that exist naturally in Gouda cheese. J. Dairy Sci. 83:1434-1440.

Schlothauer, R., L. M. Schollum, J. R. Reid, S. A. Harvey, A. J. Carr, and R. L. Fanshawe. 1999. Bioactive whey protein hydrolysate. New Zealand Dairy Board, assignee. New Zealand patent NZ508867 A (WO9965326).

Seppo, L., T. Juahiainen, T. Poussa, and R. Korpela. 2003. A fermented milk high in bioactive peptides has a blood pressure-lowering effect in hypertensive subjects. Am. J. Clin. Nutr. 77:326-330.

Seppo, L., O. Kerojoki, T. Suomalainen, and R. Korpela. 2002. The effect of a Lactobacillus helveticus LBK-16H fermented milk on hypertension-A pilot study on humans. Milchwissenschaft 57:124127.

Sieber, R., U. Bütikofer, C. Egger, R. Portmann, B. Walther, and D. Wechsler. 2010. ACE-inhibitory activity and ACE-inhibiting peptides in different cheese varieties. Dairy Sci. Technol. 90:47-73.

Silva, S. V., and F. X. Malcata. 2005. Caseins as source of bioactive peptides. Int. Dairy J. 15:1-15.

Sipola, M., P. Finckenberg, R. Koroela, H. Vapaatalo, and M. Nurminen. 2002. Effect of long-term intake of milk products on blood pressure in hypertensive rats. J. Dairy Res. 69:103-111.

Sipola, M., P. Finckenberg, J. Santisteban, R. Korpela, H. Vapaatalo, and M.-L. Nurminen. 2001. Long-term intakes of milk peptides attenuate development of hypertension in spontaneously hypertensive rats. J. Physiol. Pharmacol. 52:745-754.

Smacchi, E., and M. Gobbetti. 1998. Peptides from several Italian cheeses inhibitory to proteolytic enzymes of lactic acid bacteria, Pseudomonas fluorescens ATCC 948 and to the angiotensin-I-converting enzyme. Enzyme Microb. Technol. 22:687-694.

Smid, E. J., B. Poolman, and W. N. Konings. 1991. Casein utilization by lactococci. Appl. Environ. Microbiol. 57:2447-2452.

Stepaniak, L., L. Jedrychowski, B. Wroblewska, and T. Sorhaug. 2001. Immunoreactivity and inhibition of angiotensin-I-converting enzyme and lactococcal oligopeptidase by peptides from cheese. Ital. J. Food Sci. 13:373-381.

Upadhyay, V. K., P. L. H. McSweeney, A. A. A. Magboul, and P. F. Fox. 2004. Proteolysis in cheese ripening. Pages 391-433 in General Aspects. Cheese: Chemistry, Physics and Microbiology. Vol. 1. P. F. Fox, ed. Elsevier Academic Press, London, UK.

Visser, S., A. J. P. M. Robben, and C. J. Slangen. 1991. Specificity of a cell-envelope-located proteinase $\left(\mathrm{P}_{\mathrm{III}}\right.$-type) from Lactococcus lactis ssp. cremoris $\mathrm{AM}_{1}$ in its action on bovine $\beta$-casein. Appl. Microbiol. Biotechnol. 35:477-483.

Yamamoto, N., A. Akino, and T. Takano. 1994. Antihypertensive effect of the peptides derived from casein by an extracellular proteinase from Lactobacillus helveticus CP790. J. Dairy Sci. 77:917-922.

Yamamoto, N., M. Maeno, and T. Takano. 1999. Purification and characterization of an antihypertensive peptide from a yogurt-like product fermented by Lactobacillus helveticus CPN4. J. Dairy Sci. 82:1388-1393. 